\title{
Epistemological Character of Isomorphism in Generation of Innovation
}

\author{
${ }^{1}$ Inon Beydha, ${ }^{2}$ Sued Santos Souza Rocha de Souza, ${ }^{3}$ Flávio de São Pedro Filho, ${ }^{4}$ Maria José Aguilar \\ Madeira \\ ${ }^{1}$ University of Sumatera Utara, Medan, Indonesia \\ ${ }^{2,3}$ University of Rondonia, Brazil \\ ${ }^{4}$ University of Sumatera Utara, Medan, Indonesia
}

\begin{abstract}
This paper presents, as its overall objective, an analysis of the epistemological nature of isomorphism in the generation of innovation. To obtain the results in this study, the specific aims are as follows: (1) to raise the theoreticalconceptual basis of isomorphism in the innovation process, with regard to design; (2) to characterize the concepts inherent in the relationship of the innovation process to organizational isomorphism; and (3) to analyze the impact of isomorphism from the perspective of institutional theory. The content analysis method was used for this research, with the support of procedures for design planning. It was preceded by Internet research, bibliographical research in published books and articles, discussion, reflection, preparatory analysis and valid criticism. The results suggest that isomorphism is a common procedure for managers in organizations which seek to copy the structures or actions to obtain greater visibility and competitiveness in a specific organizational field. However, innovation is a prominent feature by which to create distinctiveness in a competitive market; it is an excellent way of changing the organizational process. Regarding the paper's theoretical contribution, it exposes the conceptual proposals of several selected authors, focusing on creative modeling for new solutions through design planning; diagrams, charts, and other suitable elements are included. Given the relevance and coverage of its theme, it is aimed at researchers and others who study innovation.
\end{abstract}

Keywords: Administration. Design planning, management, innovation, isomorphism, institutional theory.

\section{Introduction}

The main objective of this paper is to analyze the epistemological character of isomorphism in the generation of innovation. Its specific objectives were: (1) to raise the theoretical-conceptual basis of isomorphism in the innovation process considering Design Thinking; (2) characterize the concepts inherent in the relationship of the innovation process to organizational isomorphism, and (3) analyze the impact of isomorphism from the perspective of institutional theory.

The demand for innovation can be considered as a way of supporting market competitiveness, encouraging research that enriches cognitive efforts in organizational practices. In fact, technological dynamics hastens the change of structures, compelling the new to emerge in processes, products or services, among other things; adaptation is not enough to meet the demands of consumers regarding the products they can buy. In addition, obsolescence and the search for continuous improvement justify the pursuit of innovation.

This fact means not only that organizations must create something new or significantly improved; they must also adapt, invent and create, impacting on the market with new releases. This is the assumption behind the present paper, which follows the topics and subtopics of a theoretical review, the methodology of preparation, the results, the conclusion and the relevant bibliographical references. 
Inon Beydha, Sued Santos Souza Rocha de Souza,

\section{Literature Review}

Underlying this research is the Institutional Theory, which, according to Souza et al (2012), considers organizational phenomena in order to find a parameter for innovation; for these authors, these parametric phenomena are examples of isomorphism, which is a search for innovation, characterized by the hyper-competitiveness generated by the conflict between innovation and imitation. Following the same authors, isomorphism allows organizations to consolidate and become stronger since the demand for the new begins by a search for adaptive modifications that can be improved in order to achieve the aim of innovation.

\subsection{The concept of Isomorphism:}

In the view of Souza et al. (2013), isomorphism is the organizational phenomenon by which one seeks to imitate another's structures or to become similar to another. Isomorphism is classified into two types: competitive and institutional. The first focuses on market competition, and the second on its own organizational structure. Institutional isomorphism can be coercive, mimetic and normative and organizational innovation may be related to mimetic isomorphism. According to Filippetti Neto (2015), coercive isomorphism originates from pressure exerted by stakeholders; mimetic isomorphism is that in which organizations mirror themselves in market leaders, and normative isomorphism comes from the solution of similar problems faced by the firm from the professionalization of its managers. In the process of innovation, Rossoni and Filho (2011) state that, if applied irresponsibly, mimetic isomorphism can lead to disastrous effects and is difficult or impossible to remedy.

\subsection{Reflections on epistemology}

Epistemology has its basis in the philosophy of science, according to Serva (2013). This author believes that epistemology can be said to center on a rigorous analysis of rationalism, resulting in deep reflection, achieving the scientific standards of a study. Reflection of this kind requires nature and the stages and limits of human knowledge in order to observe the relationship between the subject and the inert object. This creates a causal relationship between the subject that researches and the object researched (see Figure 1 and Table 1 below). The relationship legitimates the cognitive judgment and the various structural paradigms that are common to the diverse branches of knowledge developed along its process.

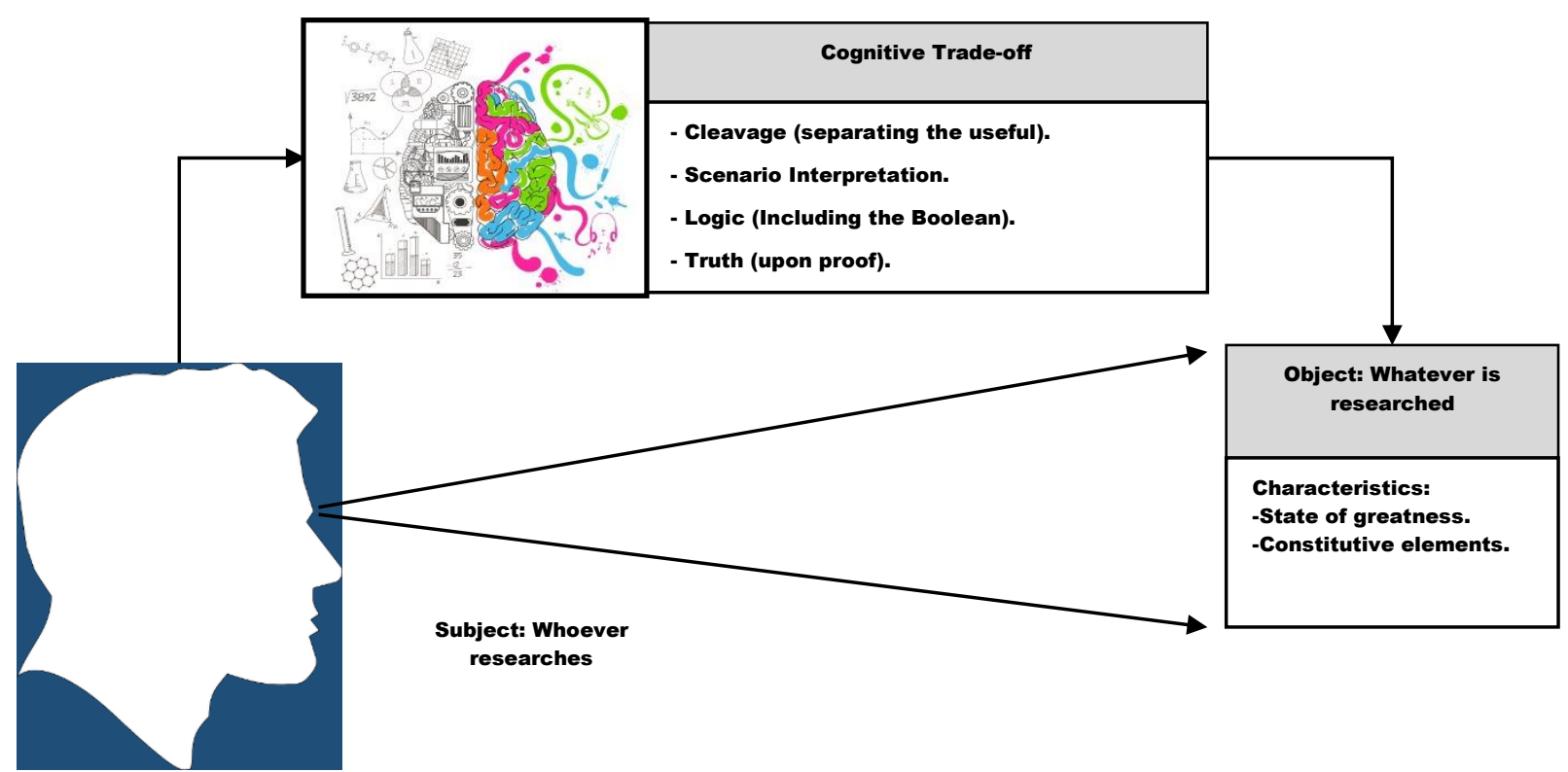

Figure 1: Mental model showing the relationship of subject $\mathrm{x}$ object in the perception of isomorphism Source: prepared by the author based on BRAGA and PEDRO FILHO (2013). 
Inon Beydha, Sued Santos Souza Rocha de Souza,

Flávio de São Pedro Filho, and Maria José Aguilar Madeira

Epistemological Character of Isomorphism in

Generation of Innovation

Table 1: Mental model showing the relation of subject $\mathrm{x}$ object in the perception of isomorphism

\begin{tabular}{|c|c|}
\hline Element & Description \\
\hline Cognitive Trade off & $\begin{array}{l}\text { It means the way to logical construction of knowledge. Under } \\
\text { isomorphism, it can reflect on the perception of the formulation of } \\
\text { choice in face of a conflict or selective pointing in the relation of loss } \\
\text { or gain. }\end{array}$ \\
\hline Cleavage & $\begin{array}{l}\text { It means the selection at the time of division between useful and } \\
\text { disposable; It involves the screening of any element that might be } \\
\text { useful. }\end{array}$ \\
\hline Scenario interpretation & $\begin{array}{l}\text { It is the locus of research and means the criticism of the surroundings } \\
\text { where the research object exists. The interpretation requires a formal } \\
\text { description of the surrounding elements since it reflects in the causal } \\
\text { relationship. }\end{array}$ \\
\hline Logic & $\begin{array}{l}\text { It means the mental mapping from which a causal relationship can be } \\
\text { inferred from proof or demonstration. }\end{array}$ \\
\hline Object & $\begin{array}{l}\text { In the present study, it means the researched element, that is, what is } \\
\text { known of the subject, and what gains a meaning in the context of an } \\
\text { investigation. }\end{array}$ \\
\hline State of greatness & $\begin{array}{l}\text { This is the compatible dimension of perception by the subject on the } \\
\text { object when it assigns a meaning with regard to a concrete } \\
\text { dimension. }\end{array}$ \\
\hline Constitutive elements & $\begin{array}{l}\text { These are the parts of the whole. In the critique of isomorphism these } \\
\text { parts may indicate an equivalence, a similarity, an inference and } \\
\text { therefore they may indicate the presence of isomorphism in its } \\
\text { diverse forms. }\end{array}$ \\
\hline Subject & $\begin{array}{l}\text { It means the one who knows, such as the researcher. This is the one } \\
\text { that opens the understanding of the causal relationship which assigns } \\
\text { the meaning of the object under investigation. }\end{array}$ \\
\hline
\end{tabular}

Source: prepared by the author on the basis of BRAGA and PEDRO FILHO (2013).

According to Capuano (2015), innovation has an epistemological character whereby an understanding of the phenomenon requires multidisciplinary approaches, being a reference in the analysis of innovation, formerly by imitation and since the Renaissance by the invention. These phenomena are due to the analysis of approaches which have their origin in human thought.

\subsection{Innovation Process}

Based on the Oslo Manual (2005), innovation has to characterize the implementation of anything new to the organization, gaining competitive advantage through five possible innovation typologies: (1) the introduction of new products;(2) a new production method; (3) the opening of new markets;(4) the development of new sources/providers of raw materials and other inputs; and (5) the creation of new market structures in an industry. The manual notes that innovation must ultimately improve performance; for this reason, companies seek to acquire advantage over their competitors when engaged in negotiations involving pricing, cost minimization, and profit amplification.

Research by Souza et al. (2013) indicates that the implementation and management of innovation stem from the sequence of process, search, and the discovery, development, updating, and commercialization of new processes or procedures, products or business. These writers state that, although some companies do not have a complete organizational structure, they can achieve efficient productivity with the release of new products. Sufficient cooperation and awareness to keep level with the competition are important factors in the innovation process, once it 
Inon Beydha, Sued Santos Souza Rocha de Souza,

Flávio de São Pedro Filho, and Maria José Aguilar Madeira

Epistemological Character of Isomorphism in

Generation of Innovation

becomes possible to measure the results of the change arising from the creation of new processes or products, by the development of new technologies.

For Bonini (2011), the development of process is directly connected to the organizations that seek to increase their efficiency and generation of innovation. At this point the epistemological character that is called Design Thinking. It is the search for innovations created by people using methods from the social context whose base is the necessity of the individual.

\subsection{Design Thinking}

Design Thinking is addressed in Silva et al. (2012) as an art able to put together science and technology in proposing new solutions. It involves management methods that are capable of generating innovation. This connection between the innovation process and the new model of idea generation is the conceptual basis of studies of the complexity inherent in the friction between innovative ideas and technology. Human creativity optimizes the processing of these new ideas in practice, which can be achieved through Design Thinking.

To Liedtka (2015), Design Thinking is still insufficiently explored by researchers. It is a process focused on innovation and emphasizing observation, collaboration, rapid learning, prototyping and simultaneous analysis.

Bonnini (2011) states that Design Thinking is a business strategy, focusing on organizational processes and supported by creative thinking. Therefore, innovation focuses directly on the individual in collaboration with others. By interacting with them one person can resolve propositions to do with problems in the optimization or improvement of ideas.

According to De Santanna (2014), the use of Design Thinking results in new business processes and is not a linear method. Thus distinguished, Design Thinking is characterized as something unstructured at first sight, but beyond doubt exploratory, if properly used in the formulation of alternative ways of solving problems. This is how Silva et al. (2012) address the practice, pointing out the three phases - immersion, ideation and prototyping - in the practice of the argumentative design of ideas. The impact of using Design Thinking results in something innovative, able to resolve intangible questions, such as the business or strategic processes in the forming of relationships between the observation of the problem and its ideation and creative analysis, or between prototyping and the implementation of the required innovation.

\subsection{Concept of Institutional Theory}

Pereira's study (2012) indicates that the emergence of Institutional Theory results from the way in which organizations incorporate prevailing practices and standards in their environment.

According to him, it is clear that organizations are now shaped by management models, standardized behaviors, and adherence to new trends, causing them to learn about implied standards and the internal diversity of organizations. In significant political contexts, the contributory factors in this sense result not from specific human actions, but from the culture itself.

Therefore, institutionalization is the transformation of beliefs and actions into rules for social conduct, which after becoming established by acceptance, bring about behavioral standardization. This reaches the social relations between the members of an institution, in a controlled manner, keeping the environment stable. Thus, the authors cite states where the resulting factor of institutionalism arises from the meeting of mimetic pressures, evidenced by the desire for organizational assimilation, which is considered successful, or legitimized, by members of the structure when they acknowledge the results.

\section{Methodology}

This paper can be classified as descriptive; it involves qualitative research carried out by an analysis of content. Bibliographical and Internet research for its preparation include the analysis of arguments by such authors as Filipe Neto (2015), Liedtka (2015), Souza (2013), Silva et al (2012), and the Oslo Manual (2005), among others, who have 
Inon Beydha, Sued Santos Souza Rocha de Souza,

brought up significant links on the topic of Isomorphism and Design Thinking. Regarding research technique, Creswell (2014) states that content analysis aims to produce inferences on the arguments which it addresses resulting from the admission of propositions, due to its connection with other propositions already accepted, making the preparation of data consistent with their analysis. Thus, articles and other publications relating to the topic were explored, as well as other material published in the last five years from approximately 40 articles listed in the Scielo, Capes and Google Scholar database.

The selected titles are linked to Design Thinking, innovation and isomorphism. Through content analysis the texts more relevant to what was proposed were evaluated, being structured in theoretical and conceptual references; the study results and conclusion and finally the evaluation of references then followed. The results are based on the interpretation of the specialist literature and on the author's own previous experience of selecting articles.

\section{Analysis of the Epistemological Character of Isomorphism on the Generation of Innovation}

Design Thinking can be considered a significant method in the creation process, thus being an issue related to innovation. It is up to academia to generate knowledge on theoretical concepts that is validated by scientific standards. In this task, isomorphism was considered as an influential way to generate innovation. Although isomorphism is identified in the market as a form of imitation, it has been applied by managers of organizations as a competitive resource; hence, it motivates the search for solutions in the competition to sell goods and services in a market. This study was developed by analyzing the positive and negative points that isomorphism presents in the innovation process, theorizing that the authors mentioned above relate to creative factors in market competitiveness.

\subsection{Survey of theoretical-conceptual basis of isomorphism in innovation processes informed by Design Thinking}

The concept of innovation means changing something existing or new and instead creating or making possible something unprecedented. A search for competitive advantage in organizations or search for a new form of existence or maintenance in the competitive market may be assumed. Managers tend to appeal to isomorphism as a reaction that will ensure the competitiveness of their organization. Table 2 below brings together the theoretical and conceptual basis and the descriptions by the authors contributing to this study.

Table 2: Theoretical-conceptual basis

\begin{tabular}{l|l}
\hline Definition & Description of the basis \\
\hline $\begin{array}{l}\text { Innovation. } \\
\text { OSLO manual (2005); Souza et al. (2013); } \\
\text { Bonini (2011). }\end{array}$ & $\begin{array}{l}\text { It is understood as a search for a competitive } \\
\text { edge, through a differentiation in a product } \\
\text { from competing products resulting from } \\
\text { efficiency and productivity in the generation } \\
\text { of new products or services. }\end{array}$ \\
\hline $\begin{array}{l}\text { Design Thinking. } \\
\text { Silva et al. (2012); Liedtka (2015); Bonini } \\
\text { (2011) e De Santana (2014). }\end{array}$ & $\begin{array}{l}\text { It is understood as a business strategy based } \\
\text { on innovation processes, redesigning the } \\
\text { model of the organization. }\end{array}$ \\
\hline $\begin{array}{l}\text { Isomorphism } \\
\text { (2015); Souza et al. (2013). }\end{array}$ & $\begin{array}{l}\text { It is understood as the attitude of an } \\
\text { organization that makes use of a similarity; a } \\
\text { way of remaining competitive through } \\
\text { imitating something successful, such as a } \\
\text { procedure, a product or the service of another } \\
\text { organization. }\end{array}$ \\
\hline
\end{tabular}

Source: prepared by the author on the basis of Internet research. 
Inon Beydha, Sued Santos Souza Rocha de Souza,

Flávio de São Pedro Filho, and Maria José Aguilar Madeira

Epistemological Character of Isomorphism in

Generation of Innovation

The Design Thinking process refers to the way of thinking of the designer; it is rarely studied in administration. It can be considered as the formulation of questions that lead to the apprehension or comprehension of phenomena in response to observational information, in order to generate consistent modeling with the desired innovation.

The strategic decision to use Design Thinking confirms the intention to make changes that lead organizations to highlight. The analysis from the perspective of utility indicates the possibility of developing and integrating new technologies However, the so-called Design Thinking search solutions are aimed at human behavior, via the development of cognitive, emotional and sensorial models; it is a process of implementing new ideas, as shown in Figure 2 and its description in Table 3 below.

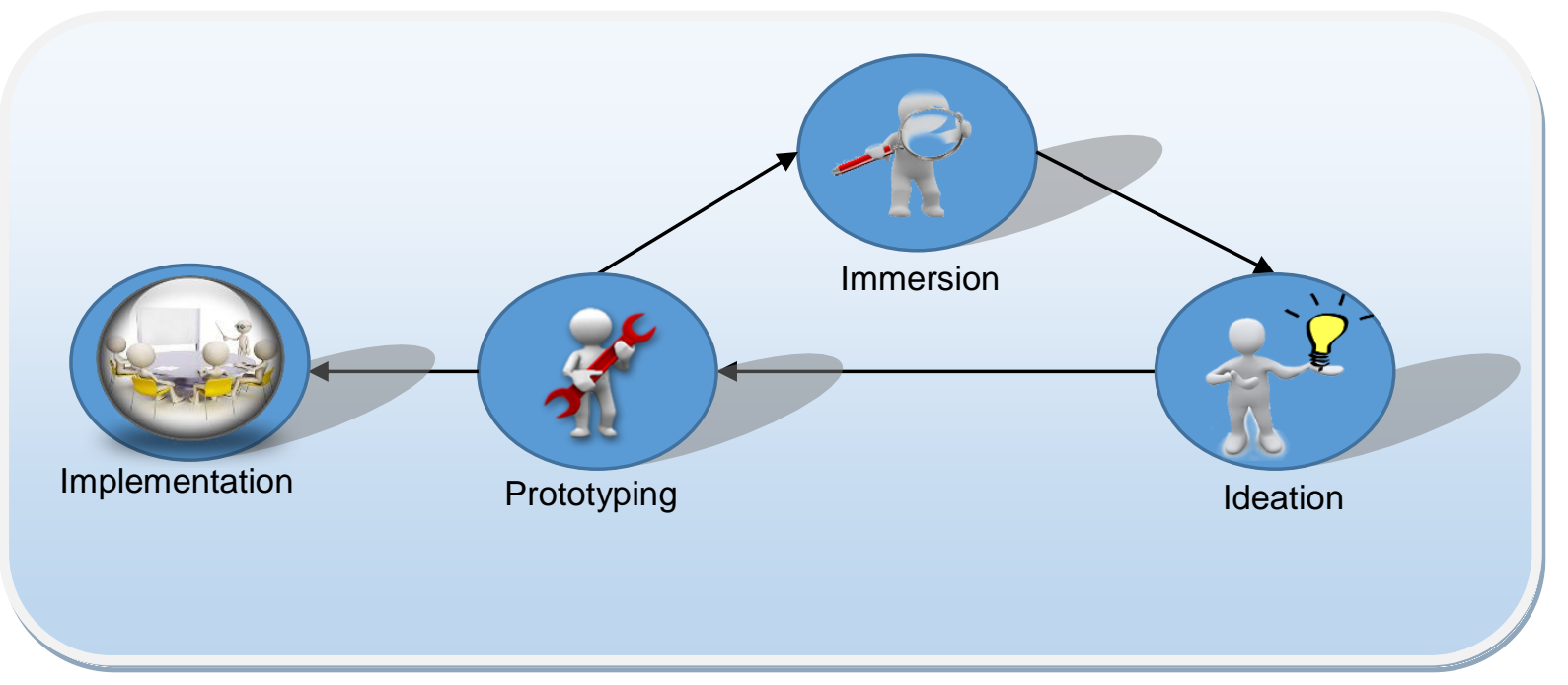

Figure 2: The design thinking

Source: prepared by the author according to Silva et al. (2012).

Table 3: Stages of Design Thinking

\begin{tabular}{l|l}
\hline Stages & \multicolumn{1}{c}{ Description } \\
\hline Immersion & $\begin{array}{l}\text { Stage where the problem is understood both from the organization's } \\
\text { point of view (client) and the end user (client of client). }\end{array}$ \\
\hline Ideation & $\begin{array}{l}\text { Stage where innovative ideas are generated, in order to propose } \\
\text { solutions within the working context. }\end{array}$ \\
\hline Prototyping & $\begin{array}{l}\text { The stage where the generated ideas are validated, possibly in } \\
\text { parallel with immersion and ideation. }\end{array}$ \\
\hline Implementation & $\begin{array}{l}\text { The process of consolidating the idea and developing validation up } \\
\text { to its being offered in the market. }\end{array}$ \\
\hline
\end{tabular}

Source: prepared by the author according to Silva et al. (2012).

\subsection{Characterization of the concepts inherent in the relationship between the innovation process and organizational isomorphism}

This section will address the particularities of the innovation process leading to isomorphism in an organization. According to the authors studied, isomorphism has three types, differentiated in Table 4 below. 
Inon Beydha, Sued Santos Souza Rocha de Souza,

Flávio de São Pedro Filho, and Maria José Aguilar Madeira

Epistemological Character of Isomorphism in

Generation of Innovation

Table 4: Types of Isomorphism

\begin{tabular}{l|l}
\hline Type & Description \\
\hline Coercion & $\begin{array}{l}\text { It is presented as a model derived from the formal or informal pressures exerted by } \\
\text { people or organizations that have a direct interest in or can indirectly be linked to } \\
\text { the outcome of a project. It is considered a form of framework given to an } \\
\text { organization by government regulations (authorities) or by organizations capable } \\
\text { of imposing standardization procedures. }\end{array}$ \\
\hline Mimetic & $\begin{array}{l}\text { It is presented as a model in which organizations start to imitate each other, free of } \\
\text { charge, usually resulting from an uncertainty in which they do not solve their own } \\
\text { problems individually, but seek ideas for success by copying similar processes } \\
\text { from other organizations. Their model is the successful organization. }\end{array}$ \\
\hline Normative & $\begin{array}{l}\text { It is presented as a model by which an organization is strengthened by a } \\
\text { knowledge base relatively focused on the professionalization of its managers. } \\
\text { Similar prevailing forms of decision-making, due to the degree of } \\
\text { professionalization, solve similar problems }\end{array}$ \\
\hline
\end{tabular}

Source: prepared by the author on the basis of Internet research.

It can be concluded from the table above that the concern for innovation is clearly due to the organization's need to create something new to fill the space or update the status of something obsolete. Souza et al. (2013) describe innovation as an escape mechanism of isomorphism in the structures and a result of the search for similarity between innovative companies. The condition conceptualized in this topic allows us to assert that the decision to equalize or innovate is crucial for the required changes. Figure 3 below sets out the elements that clarify the operation of the typology and the cognitive model of this relationship.

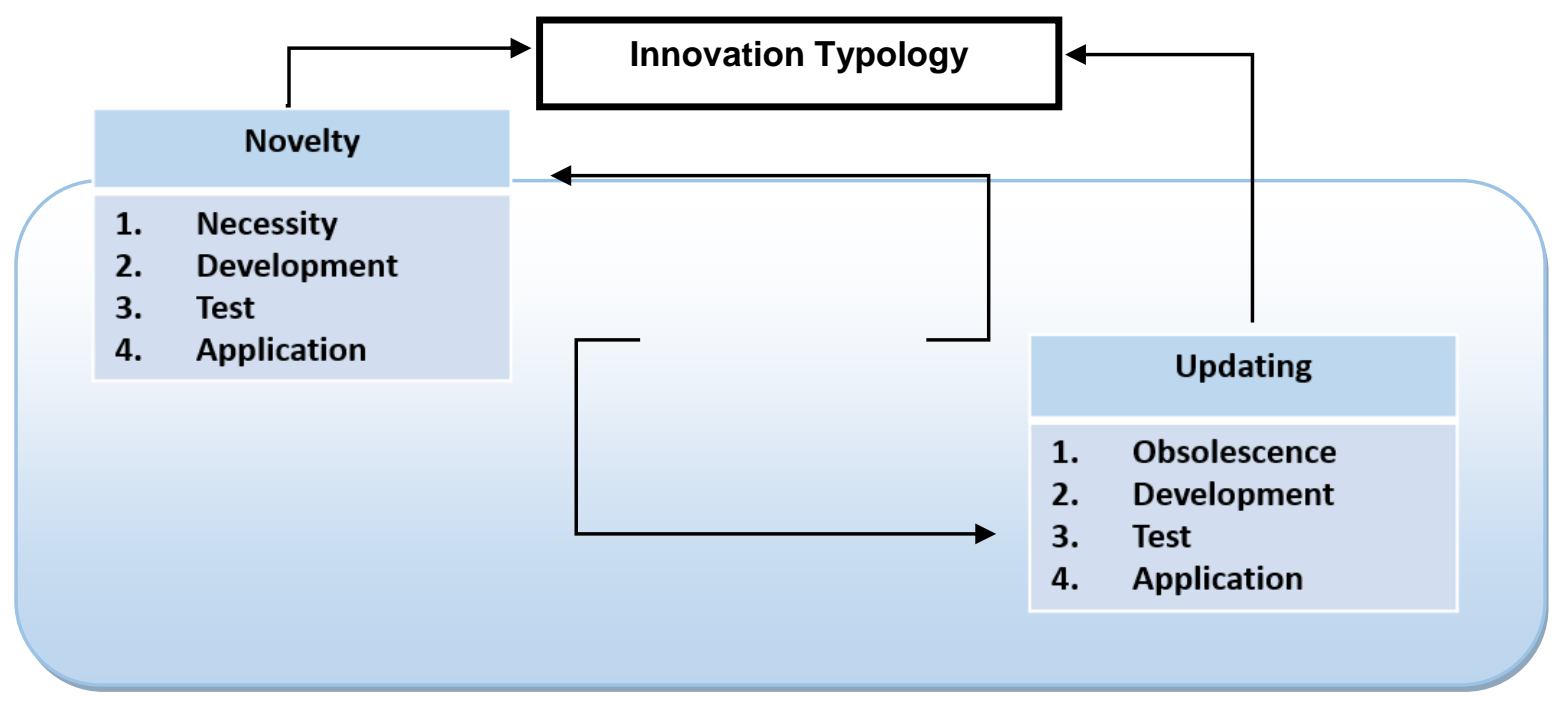

Figure 3: Types of Innovation - Cognitive Model

Source: prepared by the author on the basis of Internet research 
Inon Beydha, Sued Santos Souza Rocha de Souza,

Flávio de São Pedro Filho, and Maria José Aguilar Madeira

Epistemological Character of Isomorphism in

Generation of Innovation

Table 5: Innovation Types

\begin{tabular}{|c|c|}
\hline Element & Description \\
\hline Type of Innovation & $\begin{array}{l}\text { Relating to the concepts proposed for the third edition of the Oslo } \\
\text { Manual of OECD, (OECD, 2005, p. 55-67) }\end{array}$ \\
\hline Novelty & $\begin{array}{l}\text { Something new for the company, new to the market, and new to the } \\
\text { world, (OECD, 2005, p. 69) }\end{array}$ \\
\hline Updating & $\begin{array}{l}\text { Changes in a product or service that are lower than expected and } \\
\text { initially planned. (OECD, 2005, p. 58) }\end{array}$ \\
\hline Necessity & $\begin{array}{l}\text { Analysis of consumer information and experience of products from a } \\
\text { supplier. }\end{array}$ \\
\hline Obsolescence & $\begin{array}{l}\text { A condition in which a product or service ceases to be useful even when } \\
\text { in perfect working order due to the emergence of a more advanced } \\
\text { technology. }\end{array}$ \\
\hline Development & $\begin{array}{l}\text { Creative work carried out systematically in order to increase the stock } \\
\text { of knowledge, including human knowledge, culture and society, and the } \\
\text { use of this stock of knowledge to devise new applications (OECD, } \\
2005 \text {, p. 105). }\end{array}$ \\
\hline Test & $\begin{array}{l}\text { Operation of the provision of services with the use of new technologies } \\
\text { or trials to examine the performance of substantial improvements in } \\
\text { existing services. (OECD, 2005, p. 109). }\end{array}$ \\
\hline Application & $\begin{array}{l}\text { Results in new products, processes or services, or an improvement in } \\
\text { one or some of its attributes. }\end{array}$ \\
\hline
\end{tabular}

Source: prepared by the author on the basis of Internet research.

\subsection{Analysis of the impact of isomorphism from the perspective of Institutional Theory}

This section assesses the impact of isomorphism from the perspective of institutional theory, which, among the organizational phenomena, is a crucial point to be respected by managers even when the government imposes standards aiming more and more to homogenize companies by isomorphic mechanisms. Thus, Figure 4 consolidates the most significant impacts observed by the writers listed above, in the relationship between isomorphism and institutional theory.

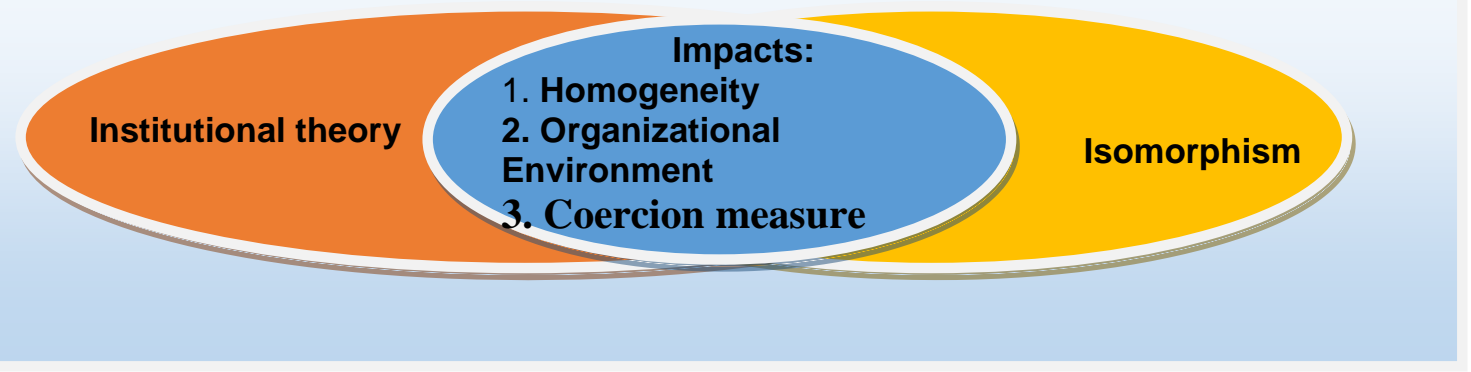

Figure 4: Impacts of isomorphism on institutional theory Source: prepared by the author on the basis of Internet research. 
Inon Beydha, Sued Santos Souza Rocha de Souza,

Flávio de São Pedro Filho, and Maria José Aguilar Madeira

Epistemological Character of Isomorphism in

Generation of Innovation

Table 6: Interpretation of impact elements

\begin{tabular}{l|l}
\hline Element & Description \\
\hline Institutional theory & $\begin{array}{l}\text { It is understood as a management model with standardized behaviors } \\
\text { and adherence to new trends, being a transformative process of beliefs } \\
\text { and actions, resulting in behavioral patterning executed by mimetic } \\
\text { pressures. }\end{array}$ \\
\hline Isomorphism & $\begin{array}{l}\text { It is understood as the attitude of an organization that makes use of a } \\
\text { similarity, a way to remain competitive through the imitation of } \\
\text { something successful, such as a procedure, a product or the service of } \\
\text { another organization. }\end{array}$ \\
\hline Homogeneity & $\begin{array}{l}\text { It is understood as the standardization of procedures, becoming a copy } \\
\text { of a standard and hence an imitation procedure. }\end{array}$ \\
\hline Organizational & $\begin{array}{l}\text { It is understood as the whole context of an organization, managed by a } \\
\text { manager, with previously consolidated rules and procedures applied. It } \\
\text { relates to anything that might influence the organization internally or } \\
\text { externally, as well as the culture of the organization. }\end{array}$ \\
\hline Coercion & $\begin{array}{l}\text { It is understood as proposed legal means to homogenize procedures } \\
\text { through coercion. Coercion is imposed for reasons arising from } \\
\text { regulatory acceptance (government or civil authorities) or the internal } \\
\text { rules of organizations. }\end{array}$ \\
\hline
\end{tabular}

Source: prepared by the author on the basis of Internet research.

Often, these isomorphic processes arise by means of coercive or persuasive elements imposed by the competent authorities, leading to the standardization of procedures; although it may allow the operational managers to have greater control, this procedure tends to reduce innovatory features a little.

Thus, the presentation of isomorphism before institutional theory brings duality to managers, being seen tendentious lays a negative review by standardization, even though, corroborating Souza's idea (2013), this standardization may awaken the motive for innovation which must be set to oppose isomorphism in the generation of new services or organizational procedures.

\section{Conclusion}

Taking the content analysis related to the proposed theme, the versatility of isomorphism may be observed both in its proposal of standardization and in relation to innovation as demanding a change in focus.

The present study identifies a connection between isomorphism and innovation; with reference to the theoretical contribution, exposing selectively the conceptual proposals of several authors, and focusing on creative modeling for new solutions through Design Thinking. It is inferred that isomorphism is a way by which managers in organizations seek to copy the structures or actions of others so as to obtain greater visibility and competitiveness in a specific organizational field. However, innovation is a prominent feature by which firms can differentiate themselves for market competitiveness. It is an excellent way of changing organizational processes. These contributions further the continuity of this study with a view to finding the point of convergence between isomorphism and creative thinking, which can be achieved through the new tool of Design Thinking. This is a topic where much remains to study. 
Inon Beydha, Sued Santos Souza Rocha de Souza,

Flávio de São Pedro Filho, and Maria José Aguilar Madeira

Epistemological Character of Isomorphism in

Generation of Innovation

\section{References}

- Bonini, Alberto, Sbragia, and Roberto (2011), Model of Design Thinking as a promoter of innovation in companies: an empirical study. Projects and Management Magazine -GeP, v. 2, n. 1, p. 03-25.

- Braga, Iluska; and Filho (2013). Handout of innovation and sustainability. Administration Postgraduate Programme. Porto Velho: UNIR/PPGMAD.

- Capuano (2015). Information on concept and Innovation Indicators. Data Grama Zero - Information Magazine - Rio de Janeiro: v.16 n.1 fev/2015.

- Creswell (2014). Qualitative investigation and research projects: choosing among five approaches. 3. ed. Porto Alegre: Penso.

- De Santanna, Isadora et al (2014). Design Thinking as a tool to improve business processes. Espacios, v. 35, n. 6 ,

- Filippetti Neto (2015), Walter Dalprat. Institutional isomorphism in the adoption of corporate social responsibility practices. 2015. 75 f. Monograph (Administration Bachelor) -University of Brasília, Brasília.

- Liedtka, Jeanne (2015). Perspective: linking design thinking with innovation outcomes through cognitive bias reduction. Journal of Product Innovation Management, v. 32, n. 6, p. 925-938, CrossRef

- Oslo Manual (2015). Guidelines for collecting and interpreting innovation data. Ed. Brasília, OCDE, Finep.

- Pereira and Fernando (2012). The evolution of the institutional theory in organizational studies: a research field to be explored. Organizations in context, São Bernardo do Campo. Year 8, n.16 jul-dec

- Rossoni, Estela, and Filho (2011). Risk of mimetic isomorphism, critical awareness, and ethical commitment. Management magazine FACES Journal, Belo Horizonte · v. $10 \cdot$ n. $4 \cdot$ pp. 42-62 - out./dez.

- Serva and Maurício (2013). The emergence and development of administration epistemology - Inferences on the contribution to te improvement of management theory. Organizational Management Magazine/RGO. Chapecó: Vol.6.

- Silva, M. J. V. et al (2012). Design thinking: Innovation in business. Rio de Janeiro: MJV, CrossRef

- Souza,et.al (2012). Innovation as Escape Mechanism of Organizational Isomorphism. São Paulo 